DOI: http://doi.org/10.31617/k.knute.2019-03-19.62

\title{
КОНТЕНТ-МАРКЕТИНГ ЯК ЗАСІБ РОЗВИТКУ БІЗНЕСУ \\ В СКЛАДНИХ НІШАХ
}

Родіонова С. O.

бакалавр маркетингу, засновниця агенції контент-маркетингу

«Content.UA», Україна

Ключові слова: просування бізнесу в складних нішах, контентмаркетинг, стратегія просування бізнесу за допомогою контенту.

Keywords: business promotion for complicated niches, content marketing, content business promotion strategy.

1. Що вважається складною нішею для бізнеса: характеристики, ознаки та особливості складних ніш.

Складними для просування нішами можна вважати ті, в яких:

- дорогий або складний у використанні продукт;

- велика кількість сильних конкурентів на ринку;

- дуже вузька або, навпаки, дуже широка цільова аудиторія;

- довгий шлях до покупки, багато факторів прийняття рішення тощо.

2. Особливості контентного просування бізнесу в складних нішах.

Не завжди очевидно, на яких майданчиках шукати ЦА продукту і як із нею комунікувати. На перший погляд, аудиторію складних ніш потрібно шукати в LinkedIn, але в результаті може виявитися, що з тими самими IT-фахівцями набагато простіше спілкуватися в Instagram або Facebook. Необхідно лише знайти правильний тон комунікації.

Соцмережі потрібно розвивати обов'язково. Навіть якщо сьогодні більшість ЦА продукту користується ними рідко. Картина швидко змінюється, і вже тепер, якщо вашого бізнесу немає в соцмережах, можна вважати, що його немає взагалі. Отже, комунікувати з аудиторією треба через якомога більшу кількість каналів.

Email-розсилки по підготовленій базі допомагають комунікувати 3 аудиторією, яка мало користується соцмережами. Розсилка дозволяє зробити спілкування максимально персоналізованим і надати людині саме ту інформацію, що ії з більшою ймовірністю зацікавить. 
Якщо аудиторія дуже широка (наприклад, ноутбуки використовують і домогосподарки, і студенти, і бізнесмени), потрібно розробити контент-стратегію та філософію просування, щоб врахувати інтереси й запити кожного сегмента, але не змішувати адресовані їм статті та меседжі.

Якщо аудиторія - професіонали, говорити з ними варто професійною мовою. Для цього команді, яка працює з контентом, потрібно глибоко розібратися в темі та знайти грамотного куратора, технічного редактора.

Якщо ніша висококонкурентна, просування за високочастотними запитами може не дати результатів, бо їх активно використовують лідери галузі. А от просування за великою кількістю низько- та середньочастотних запитів допомагає швидко зібрати трафік.

Виходячи на трастові майданчики та до профільних 3МI, варто враховувати, що це територія експериментів. Публікації можуть не дати очікуваних результатів або, навпаки, дати трафік із неочікуваних ресурсів. Водночас таргетована реклама в соціальних мережах дозволяє досить швидко й порівняно дешево оцінити обсяг і залученість аудиторії, теми, на які вона реагує, тощо.

3. Етапи просування в складних нішах: цілі, задачі та методи роботи.

Аналітика. Вивчаємо нішу, цільову аудиторію, конкурентів та їхній реферальний трафік тощо.

Розробка стратегії просування. Залежно від потреб бізнесу прописуємо гіпотези, тестуємо їх та обираємо найефективніші канали просування. Прописуємо КРI для кожного каналу.

Реалізація кроків, передбачених стратегією. Залежить від продукту, цільової аудиторії, відомості бренда та інших факторів.

Контроль. Відстежуємо показники КРI та за потреби коригуємо напрям і методи просування.

4. Підбір команди для складного проекту.

За проектом закріплюється пул авторів, підбирається технічний редактор, що контролює фактаж, та літредактор, що відповідає за якість текстів. У деяких випадках - ще й коректор.

Ми просимо замовника організувати для контент-команди навчання 3 тренером стосовно продукту, щоб максимально ознайомити авторів із темою. 
У процесі роботи відсіюємо авторів, що не справляються з темою, та добираємо нових.

5. Побудування взаємодії зі спеціалістами на боці замовника

Просимо замовника призначити спеціаліста, який може оперативно надавати інформацію щодо проекту та узгоджувати виконані роботи згідно з контент-маркетинговою стратегією.

Визначаємо граничну кількість ітерацій правок для кожного виду контенту.

Призначаємо контентні інтерв'ю зі спеціалістами на боці замовника для отримання актуальної інформації та створення корисного й глибокого контенту.

6. Контроль та вимірювання результатів контентного просування в складних нішах.

Регулярно стежимо за показниками, важливими для конкретного проекту. Серед них: охоплення та залученість у соцмережах, переходи на сайт та поведінкові фактори користувачів, показники ефективності реклами тощо.

Якщо KPI не досягнуті, виявляємо причину й коригуємо або плани, або дії.

7. Складнощі та перешкоди, що можуть виникнути під час реалізації контент-маркетингової стратегії.

Неготовність замовника співпрацювати та надавати інформацію для створення якісного контенту.

Намагання замовника надмірно контролювати процеси на боці агенції, необгрунтовані вимоги до текстів: «Мені не подобається, перепишіть».

Розсинхрованння дій різних команд, що працюють над просуванням. Наприклад, контентна команда вже «розхитала» соцмережі, підняла цікавість до продукту, а команда розробників досі не допрацювала сайт. Трафік нема куди спрямовувати, отже, продажів немає.

Серед неочевидних факторів - неготовність власника бізнесу до суттєвих змін, які несе 3 собою просування. У результаті він неусвідомлено саботує дії з боку агенції.

Висновки. Просування в складних нішах потребує уважного вивчення аудиторії та іiї запитів.

Для підготовки контенту важливо обирати авторів, що вже знаються на темі, або забезпечувати їм якісні тренінги з продукту та суміжних питань. 
Потрібно на старті визначити з замовником, хто та яким чином буде надавати необхідну інформацію, коментувати та узгоджувати тексти. На початку роботи коментарі текстів від замовників обов'язкові.

Важливо розуміти, що перші місяці роботи підуть на відпрацювання гіпотез, аналіз показників та визначення найдієвіших методів для конкретного бізнесу. Отже, не варто очікувати швидких результатів.

DOI: http://doi.org/10.31617/k.knute.2019-03-19.63

\title{
СПОЖИВАЧ TА DIGITAL: ЩО ВПЛИВАЕ НА КОГО?
}

\author{
Романченко Т. В. \\ аспірантка \\ кафедра маркетингу \\ Київський національний торговельно-економічний університет, \\ Украӥна
}

Ключові слова: діджиталізація реклами, контент, віртуальна реальність.

Keywords: digital advertising, $V R$ and IR, content.

Новітні технології і поява нових типів даних змінюють динаміку ринків, поведінку споживачів, взаємодію виробників продукції чи послуг і рекламних агенств. Розповсюдження мобільних пристроїв, які вже давно стали більше, ніж засіб зв'язку, безпосередньо впливає на звички та споживання контенту. В Україні, за даними дослідження We Are Social та Hootsuite, станом на 2018 рік проживає 25,6 мільйонів інтернет-користувачів, що складає 58\% всього населення. Лише 13 мільйонів 3 них користуються соцмережами, а мобільними телефонами для спілкування в інтернеті - 9,5 мільйонів.

Друге щорічне дослідження Adobe Consumer Content Survey опитування в грудні 2018 року серед 1000 американських споживачів, які володіють принаймні одним цифровим пристроєм - показало, що споживання цифрового контенту зростає і споживачі мають певні очікування та переваги, з якими рекламодавці не можуть не рахуватися.

Було виявлено п'ять споживчих тенденцій формування споживання цифрового контенту. 